\title{
Fryns Syndrome in Monozygotic Twins - A Case Report with Review of Literature
}

\author{
Síndrome Fryns en Gemelos Monocigóticos - Reporte de Caso con Revisión de la Literatura \\ Nirmaladevi, M.; Sandhya Kurup \& Ajitha, E. V.
}

NIRMALADEVI, M.; KURUP, S. \& AJITHA, E. V. Fryns syndrome in monozygotic twins - a case report with review of literature. Int. J. Morphol., 30(1):56-60, 2012.

SUMMARY: Fryns syndrome is a rare multiple congenital anomaly syndrome. The syndrome is characterized by congenital diaphragmatic hernia, unusual facial features and distal limb abnormalities. Here we report a case of monozygotic twins with Fryns syndrome of consanguine parents with normal first child. The mother with 20 weeks of gestation having hyperemesis was referred from a primary health centre to the department of obstetrics and gynaecology at our hospital with polyhydramnios detected in ultrasonogram. Detailed ultrasound was done and after finding that both babies having multiple congenital anomalies, emergency caeserian section was done. The malformations in the twins suggestive of Fryns syndrome.

KEY WORDS: Congenital diaphragmatic hernia; Polyhydramnios; Malformations.

\section{INTRODUCTION}

Fryns syndrome is a rare autosomal recessive disorder with multiple congenital anomalies. It was first described in 1979 by Fryns et al. (1979). The incidence of this syndrome is $0.7-1$ in 10,000 births. The most common defect in Fryns syndrome is a congenital diaphragmatic hernia leading to hypoplasia of lungs, craniofacial abnormalities (coarse face, microophthalmia, broad and flat nasal bridge, low-set ears and micrognathia) and hypoplasia of distal limbs (Fryns et al.; Fryns, 1987; Fryns \& Moerman, 1998). The associated anomalies are renal dysplasia, renal cortical cysts, malformations involving brain, cardiovascular system, gastrointestinal system and genitalia. In these cases Pregnancy is often complicated by polyhydramnios and preterm delivery. Because of its rare presence especially in monozygotic twins the case was studied in detail and presented.

\section{CASE REPORT}

A 29-year old mother with her second pregnancy came to the department of obstetrics and gynaecology with 20 weeks of gestation and history of hyperemesis. Her first child was normal and 4 years old. There is history of consanguinity. A detailed ultrasonogram was done which showed polyhydramnios, twin pregnancy with multiple congenital anomalies. An emergency caeserian section was done and the twins were delivered.

The first female fetus (weight: 400g) had the following anomalies (Figs. 1 and 2):

- Head: microcephaly, low set ears, micrognathia and flat nasal bridge.

- Upper limb: short forearm with only four fingers on both sides.

- Lower limb: inverted and adducted with five toes on both sides.

- Thorax: left side was filled with spleen, stomach, coils of small intestine and part of liver along with heart and hypoplastic lungs pushed to right side.

- Diaphragm: deficient, only small slips were present on right side suggestive of diaphragmatic hernia.

- Abdomen and Pelvis: large intestine and kidneys were present with uterus, tubes and ovaries in pelvis.

The second female fetus (weight: $450 \mathrm{~g}$ ) had the following anomalies (Figs. 1 and 2): 


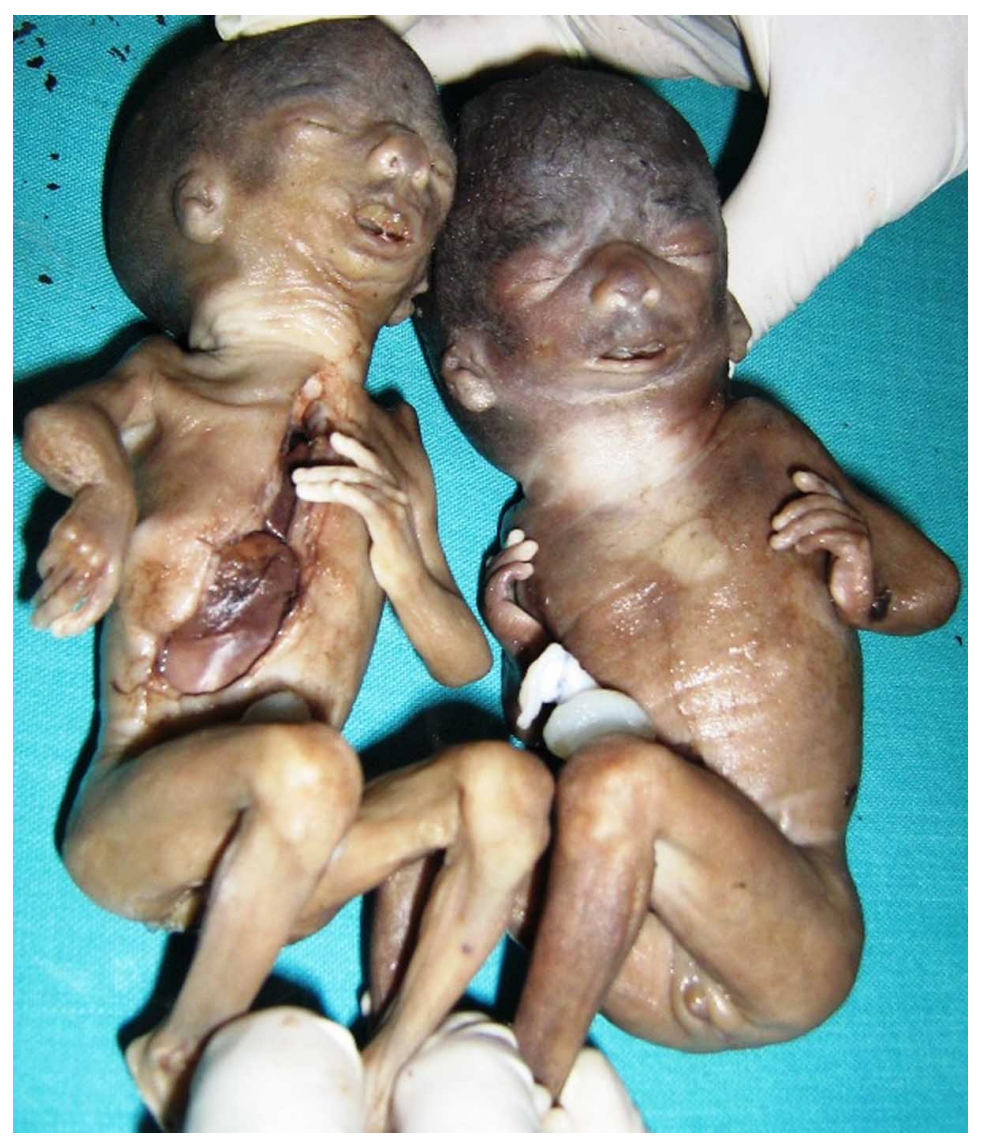

Fig. 1. Twins with Fryns syndrome showing low set ears, micrognathia \& distal limb hypoplasia.
- Head: microcephaly, low set ears, micropnathia and flat nasal bridge.

- Upper limb: short forearm with only four fingers on both sides.

- Lower limb: inverted and adducted with five toes on right side and foue toes on left side (second toe was not present).

- Thorax: left side was filled with spleen, stomach, coils of small intestine and part of liver along with heart and hypoplastic lungs pushed to right side.

- Diaphragm: deficient, only small slips were present on right side suggestive of diaphragmatic hernia.

- Abdomen and Pelvis: large intestine and kidneys were present with uterus, tubes and ovaries in pelvis.

Radiographs were taken to assess the skeletal anomalies. Both fetuses had short radius and ulna on both sides, only four metacarpals on both upper limbs and five metatarsals on right and four metatarsals on left side. Spine and other bones were normal (Fig. 3).
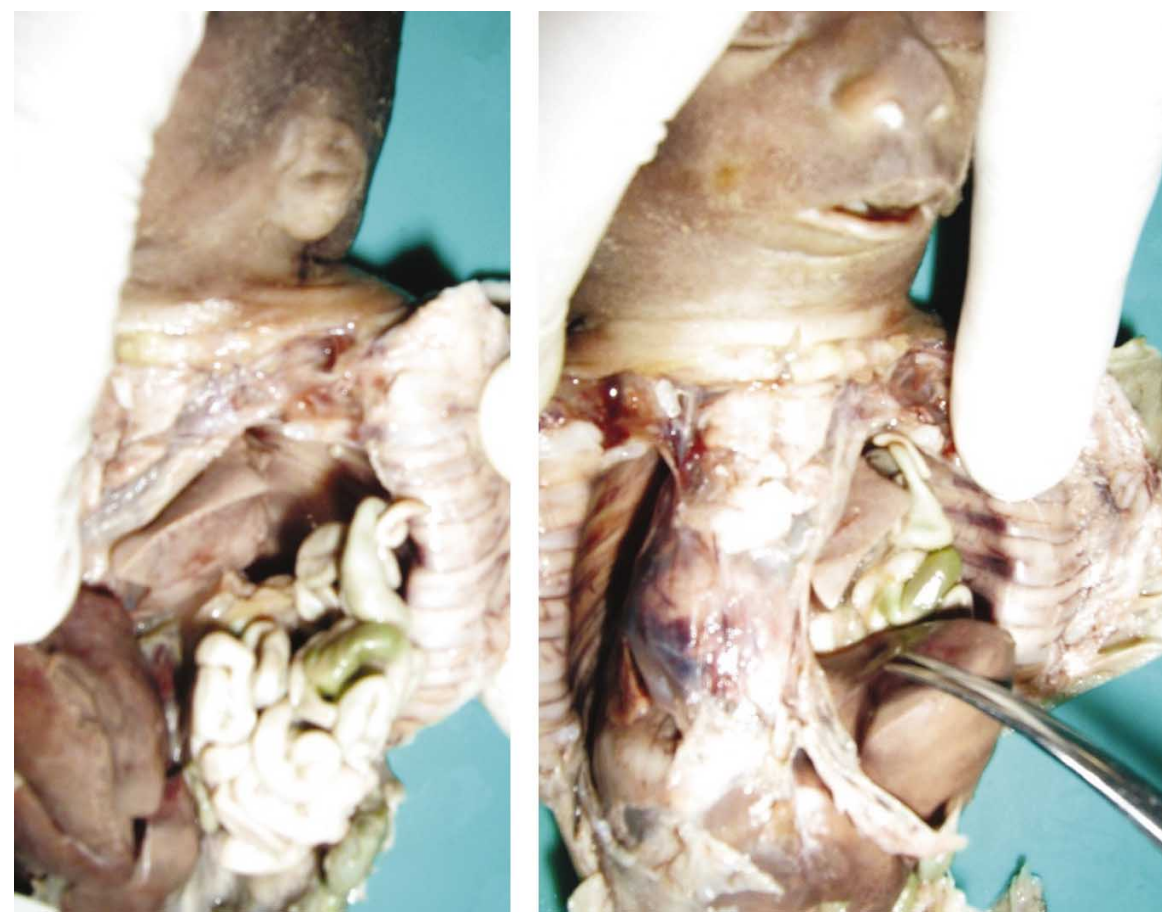

Fig. 2. Congenital diaphragmatic hernia in twins. 

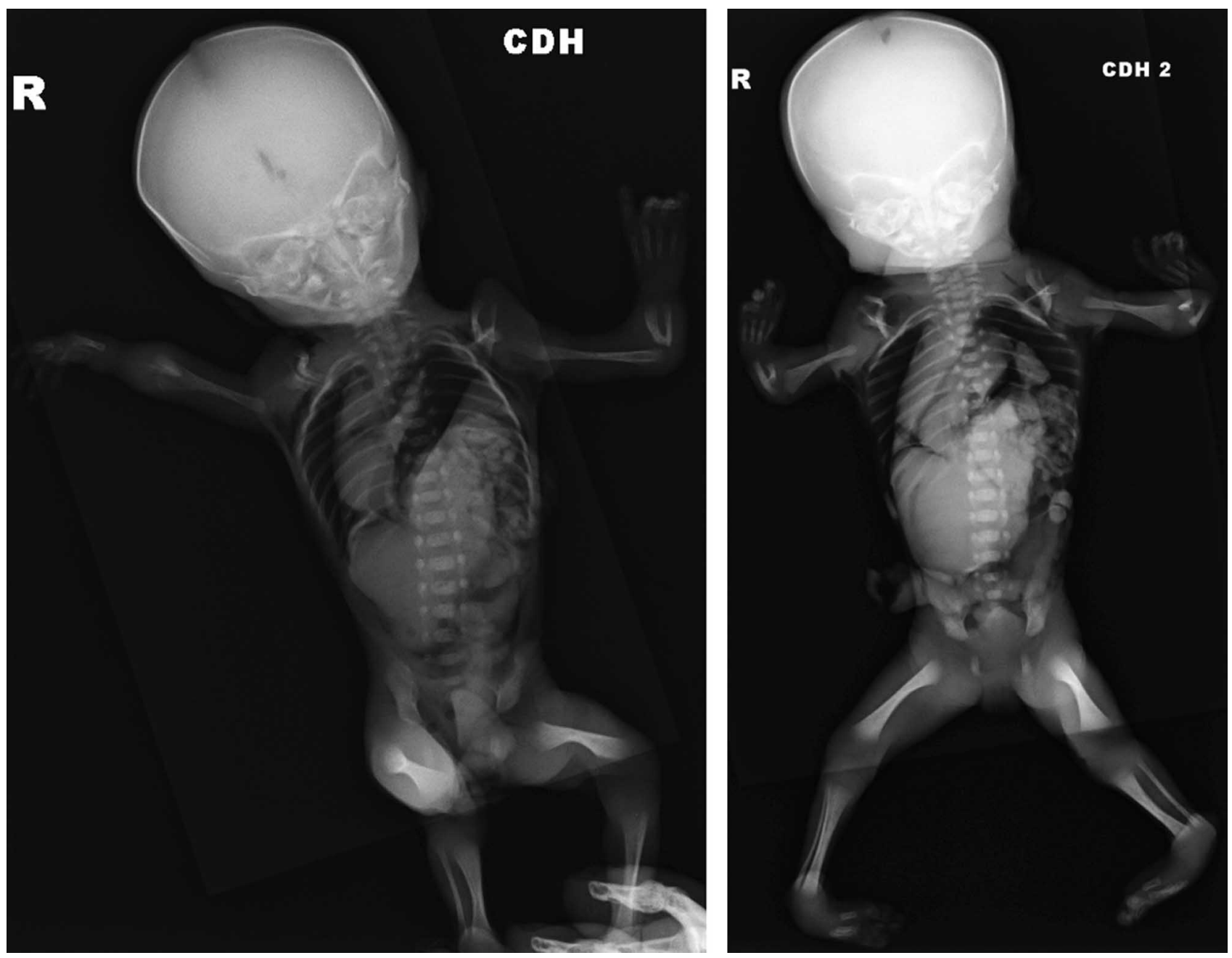

Fig. 3. Radiograph showing skeletal abnormalities.

\section{DISCUSSION}

Fryns syndrome is an autosomal recessive, rare multiple congenital anomaly syndrome with an incidence of 0.7 per 10000 births. The six diagnostic criteria for Fryns Syndrome are as follows: 1) diaphragmatic defect, 2) characteristic facial appearance, 3) distal digital hypoplasia, 4) pulmonary hypoplasia, 5) characteristic associated anomalies like polyhydramnios, brain malformations, renal dysplasia, gastrointestinal system malformations and genital malformations and 6) Parental consanguinity (Lin et al., 2005). At least three findings should be present for Fryns syndrome but in the present case all six criteria were present.

Fryns syndrome may be the most common autosomal recessive syndrome in which congenital diaphragmatic hernia is a cardinal feature (Aymé et al., 1989; Slavotinek et al., 2005). Vargas et al. (2000) reported a pair of monozygotic twins with Fryns syndrome discordant for severity of diaphragmatic defect. Both twins had macrocephaly, coarse facial appearance, hypoplasia of distal phalanges, and an extra pair of ribs. Twin A lacked an apparent diaphragmatic defect, and at 1 year of age had mild developmental delay. Twin B had a left congenital diaphragmatic hernia and died neonatally. The authors suggested that absence of diaphragmatic defect in Fryns syndrome may represent a subpopulation of more mildly affected patients. In the present case both fetuses had almost same anomalies specifically diaphragmatic hernia.

Pierson et al. (2004) reviewed 77 reported patients with Fryns syndrome and summarized the abnormal eye findings identified in 12 of them. They also described 3 new patients with Fryns syndrome, 1 of whom demonstrated 
unilateral microphthalmia and cloudy cornea. In the present cases there was no eye anomaly was detected. Arnold et al. (2003) reported a male fetus with Fryns syndrome and additional abnormalities, in particular, multiple midline developmental defects including gastroschisis, central nervous system defects with left arrhinencephaly and cerebellar hypoplasia, midline cleft of the upper lip, alveolar ridge, and maxillary bone, and cleft nose with bilateral choanal atresia. All these findings were absent in the present case.

Fryns Syndrome has a high mortality rate. About $36.5 \%$ of fetuses die before 36 weeks gestation and $32.2 \%$ were born alive after 36 weeks but died within the first days of life (Van Hove et al., 1995).

The differential diagnosis for Fryns Syndrome are PaIlister-Killian Syndrome (dysmorphic syndrome with tissue-specific mosaicism of tetrasomy 12p) (McPherson et al., 1993), Cornelia de Lange syndrome and trisomy 22 (Jones, 1997).
The exact cause of Fryns syndrome is unknown. The disorder is thought to be genetic because it tends to run in families and has features similar to those of other genetic disorders. However, no specific genetic change has been found to cause all of the signs and symptoms of this disorder. A significant inter and intra-familial phenotypic variability as well as discordant phenotype in monozygotic twins has been reported (Ramsing et al., 2000; Vargas et al., 2000).

Even though no specific genetic cause had been identified, certain chromosomal abnormalities have been described in cases of Fryns Syndrome, including mosaicism for a tandem duplication of chromosome 1q24-q31.2, ring chromosome 15, terminal deletion of chromosome $6 \mathrm{q}$, trisomy 22, and XO karyotype (Clark \& Fenner-Gonzales, 1989).

Fryns syndrome has a high rate of stillbirth and early neonatal mortality. Prenatal diagnosis especially ultrasonogram done in early weeks of pregnancy can be useful in identifying this fatal syndrome.

NIRMALADEVI, M.; KURUP, S. \& AJITHA, E. V. Síndrome Fryns en gemelos monocigóticos - reporte de caso con revisión de la literatura. Int. J. Morphol., 30(1):56-60, 2012.

RESUMEN: El síndrome de Fryns, es un raro síndrome de múltiples anomalías congénitas. El síndrome se caracteriza por la hernia diafragmática congénita, rasgos faciales inusuales y alteraciones distales del miembro. Se presenta un caso de gemelos monocigóticos con síndrome de Fryns de padres consanguíneos con un primer hijo normal. La madre con 20 semanas de gestación e hiperemesis fue remitida desde un centro de salud primario al departamento de obstetricia y ginecología de nuestro hospital con polihidramnios detectado en ecografía. En una ecografía detallada se evidenció que los dos bebés tenían múltiples anomalías congénitas, por lo que se realizó una cesárea de emergencia. Las malformaciones en los gemelos sugieren un síndrome de Fryns.

PALABRAS CLAVE: Hernia diafragmática congénita; Polihidramnios; Malformaciones.

\section{REFERENCES}

Arnold, S. R.; Debich-Spicer, D, D.; Opitz, J. M. \& GilbertBarness, E. Documentation of anomalies not previously described in Fryns syndrome. Am. J. Med. Genet. A, 116A:179-82, 2003.

Aymé, S.; Julian, C.; Gambarelli, D.; Mariotti, B.; Luciani, A.; Sudan, N.; Maurin, N.; Philip, N.; Serville, F.; Carles, D.; Rolland, M. \& Giraud, F. Fryns syndrome: report on 8 new cases. Clin. Genet., 35:191-201, 1989.

Clark, R. D. \& Fenner-Gonzales, M. Apparent Fryns syndrome in a boy with a tandem duplication of 1q24-31.2. Am. J. Med. Genet., 34:422-6, 1989.

Fryns, J. P.; Moerman, F.; Goddeeris, P.; Bossuyt, C. \& Van den Berghe, H. A new lethal syndrome with cloudy corneae, diaphragmatic defects, and distal limb deformities. Hum. Genet., 50:65-70, 1979.

Fryns, J. P. Fryns syndrome: a variable MCA syndrome with diaphragmatic defects, coarse face, and distal limb hypoplasia. J. Med. Genet., 24:271-4, 1987.

Fryns, J. P. \& Moerman, P. Scalp defects in Fryns syndrome. Genet. Couns., 9:153-4, 1998.

Jones K. L. Smith's Recognizable Patterns of Human Malformation. $5^{\text {th }}$ ed. Philadelphia, WB Saunders, 1997. p.210.

Lin, A. E.; Pober, B. R.; Mullen, M. P. \& Slavotínek, A. M. Cardiovascular malformations in Fryns syndrome: is there a 
pathogenic role for neural crest cells? Am. J. Med Genel. A, 139:186-93, 2005.

McPherson, E. W.; Ketterer, D. M. \& Salsburey, D. J. PallisterKillian and Fryns syndromes: nosology. Am. J. Med. Genet., 47:241-5, 1993.

Pierson, D. M.; Taboada, E. \& Butler, M. G. Eye abnormalities in Fryns syndrome. Am. J. Med. Genet. A, 125A:273-7, 2004.

Ramsing, M.; Gillessen-Kaesbach, G.; Holzgreve, W.; Fritz, B. \& Rehder, H. Variability in the phenotypic expression of Fryns syndrome: report of two sibships. Am. J. Med. Genet., 95:41524, 2000 .

Slavotinek, A.; Lee, S. S.; Davis, R.; Shrit, A.; Leppig, K. A.; Rhim, J.; Jasnosz, K.; Albertson, D. \& Pinkel, D. Fryns syndrome phenotype caused by chromosome microdeletions at $15 \mathrm{q} 26.2$ and 8p23.1. J. Med. Genet., 42:730-6, 2005.

Van Hove, J. L.; Spiridigliozzi, G. A.; Heinz, R.; McConkie-Rosell, A.; Iafolla, K. \& Kahler, S. G. Fryns syndrome survivors and neurologic outcome. Am. J. Med. Genet., 59:334-40, 1995.

Vargas, J. E.; Cox, G. F. \& Korf, B. R. Discordant phenotype in monozygotic twins with Fryns syndrome. Am. J. Med. Genet., 94:42-5, 2000.

\section{Correspondence to: Dr. Nirmaladevi M. Assistant Professor Dept. of Anatomy MOSC Medical College Kolenchery Ernakulam, Kerala - 682311 INDIA}

Mobile:+91-9961969636

Email: drnirmaladevianatomy@gmail.com

Received: 29-06-2011

Accepted: 01-08-2011 